\title{
Renal Contributions in the Pathophysiology and Neuropathological Substrates Shared by Chronic Kidney Disease and Alzheimer's Disease
}

\author{
Gabriela Dumitrita Stanciu ${ }^{1}(D)$, Daniela Carmen Ababei ${ }^{2, *}$, Veronica Bild ${ }^{2}$, Walther Bild ${ }^{3}$, \\ Luminita Paduraru ${ }^{4, *(1)}$, Mihai Marius Gutu ${ }^{5}$ and Bogdan-Ionel Tamba ${ }^{1,6}$ (D) \\ 1 Center for Advanced Research and Development in Experimental Medicine (CEMEX), "Grigore T. Popa" \\ University of Medicine and Pharmacy, 16 Universitatii street, 700115 Iasi, Romania; \\ gabriela-dumitrita.s@umfiasi.ro (G.D.S.); bogdan.tamba@umfiasi.ro (B.-I.T.) \\ 2 Pharmacodynamics and Clinical Pharmacy Department, "Grigore T. Popa" University of Medicine and \\ Pharmacy, 16 Universitatii street, 700115 Iasi, Romania; veronica.bild@gmail.com \\ 3 Department of Physiology, "Grigore T. Popa” University of Medicine and Pharmacy, 16 Universitatii street, \\ 700115 Iasi, Romania; walther.bild@umfiasi.ro \\ 4 Department Mother \& Child Care, Division Neonatology, “Grigore T. Popa” University of Medicine and \\ Pharmacy, 16 Universitatii street, 700115 Iasi, Romania \\ 5 Department of Biophysics and Medical Physics-Nuclear Medicine, "Grigore T. Popa" University of Medicine \\ and Pharmacy, 16 Universitatii street, 700115 Iasi, Romania; marius.gutu@umfiasi.ro \\ 6 Department of Pharmacology, Clinical Pharmacology and Algesiology, "Grigore T. Popa” University of \\ Medicine and Pharmacy, 16 Universitatii street, 700115 Iasi, Romania \\ * Correspondence: dana.ababei@gmail.com (D.C.A.); luminita.paduraru@gmail.com (L.P.)
}

Received: 30 June 2020; Accepted: 14 August 2020; Published: 17 August 2020

check for updates

\begin{abstract}
Chronic kidney disease and Alzheimer's disease are chronic conditions highly prevalent in elderly communities and societies, and a diagnosis of them is devastating and life changing. Demanding therapies and changes, such as non-compliance, cognitive impairment, and non-cognitive anomalies, may lead to supplementary symptoms and subsequent worsening of well-being and quality of life, impacting the socio-economic status of both patient and family. In recent decades, additional hypotheses have attempted to clarify the connection between these two diseases, multifactorial in their nature, but even so, the mechanisms behind this link are still elusive. In this paper, we sought to highlight the current understanding of the mechanisms for cognitive decline in patients with these concurrent pathologies and provide insight into the relationship between markers related to these disease entities and whether the potential biomarkers for renal function may be used for the diagnosis of Alzheimer's disease. Exploring detailed knowledge of etiologies, heterogeneity of risk factors, and neuropathological processes associated with these conditions opens opportunities for the development of new therapies and biomarkers to delay or slow their progression and validation of whether the setting of chronic kidney disease could be a potential determinant for cognitive damage in Alzheimer's disease.
\end{abstract}

Keywords: chronic kidney disease; Alzheimer's disease; cognitive impairment; neuropathological substrates; pathophysiology

1. Prevalence, Socio-Economic Aspects, and the Relationship between Chronic Kidney Disease and Alzheimer's Disease

Globally, dementia represents one of the most important social, economic, and public health challenges with extended human life expectancy. Epidemiological survey has estimated that 50 million 
individuals around the world suffered from dementia in 2018, with Alzheimer's disease (AD) comprising 60 to $80 \%$ of all cases, and the number is projected to triple by 2050 [1,2], mostly due to an elderly population but also to a growing prevalence of risk factors for dementia. The estimated total annual worldwide costs for care of AD people was USD 1 trillion in 2018, and this figure will rise to approximately USD 2 trillion by 2030. The fundamental risk factor for the development of AD is increased age [3-5]. Other recognized risk factors include family history [6], degeneration or vascular dysfunction [7,8], obesity [9], hypotension or hypertension [10], diabetes [11-13], hyperlipidemia [14,15], low levels of education, physical inactivity [16], and the existence of epsilon 4 allele of the apolipoprotein E gene (ApoE4) [6,17]. A recently proposed modifiable risk factor for AD is kidney disease. The amyloid precursor protein (APP) expression level in kidney disease patients is higher. It is a key protein for protein-bound receptor sorting (SorLA), which acts as a central regulator of APP trafficking and processing and is expressed concurrently in both neurons (cerebellum, hippocampus, and cortex), renal cells, and gene polymorphism, which is associated with late-onset AD [18-23].

Chronic kidney disease (CKD), also known as chronic kidney failure, defines a gradual loss of renal function that persists for three or more months; it is an essential contributor to mortality and morbidity from non-communicable conditions. The progression of disease is divided into a five distinct-stage system, as defined by the Kidney Disease Outcomes Quality Initiative (KDOQI) Clinical Practice Guidelines (Table 1) [24], focused on the estimated glomerular filtration rate (eGFR), a calculation of waste cleared by the kidneys per minute [25]. According to existing estimates, 697.5 million people (9.1\%) were afflicted by CKD worldwide, with CKD stages 1-2 accounting for 5\%, stage 3 for 3.9\%, stage 4 for $0.16 \%$, stage 5 for $0.07 \%$, dialysis for $0.041 \%$, and kidney transplantation for $0.011 \%$, causing 1.2 million deaths in 2017 [26]. In recent decades, the costs of CKD therapy have increased with accessibility of renal replacement techniques [27], whereas over 2.5 million people have benefited from replacement therapy so far, and it is expected to double to 5.4 million by 2030 [28]. However, the most expensive treatment seems to be for patients with end-stage renal disease (ESRD). In the latest report, the Centers for Disease Control and Prevention announced costs of USD 84 billion for CKD of which USD 36 billion only was for ESRD [26].

CKD can be initiated by a renal condition or can occur as a result of complications caused by multisystem disorders associated with comorbidities, such as diabetes mellitus type 2, which at present represents the most important factor of this disease globally. This condition is considered to be an independent risk factor for cognitive decline and dementia [25,29,30]. Dementia represents an essential complication, as it may lead to reduced medical adherence education and health literacy and is a robust, independent predictor of mortality in individuals suffering from dialysis [31]. Cognitive impairment prevalence in dialysis people has been described to be around 30 to $60 \%$ [32], and cases under hemodialysis have lower cognitive outcomes, mainly in attentional control, executive function fields, and orientation compared with patients on peritoneal dialysis [31,33]. The relationship between cognitive decline and CKD can be clarified by some factors, such as traditional risk factors, non-traditional risk factors, increased inflammation, and oxidative stress (Figure 1) [25,32,34]. Anemia, polypharmacy, hyperparathyroidism, depression, and sleep disorders may represent a supplementary link between cognitive decline and CKD. Moreover, patients under dialysis are exposed to hypoxemia, proinflammatory state, extensive fluid and osmolar shifts, and fluctuant concentrations of uremic toxins [32]. The latest data reveal that both the occurrence and evolution of cognitive decline are inversely related with the CKD stage. A current meta-analysis of cross-sectional and longitudinal studies including 54,779 people revealed that for every $10 \mathrm{~mL}$ reduction in the eGFR value below $60 \mathrm{~mL} / \mathrm{min} / 1.73 \mathrm{~m}^{2}$ an intensification is registered in the risk of cognitive impairment of 11\% [35]. Furthermore, another part of the studies showed a more accelerated decrease in cognitive abilities over time when CKD is present $[31,36]$. 
Table 1. Chronic kidney disease staging definitions and correspondence with Kidney Disease Outcomes Quality Initiative (KDOQI) Clinical Practice Guidelines categories.

\begin{tabular}{ccc}
\hline $\begin{array}{c}\text { Chronic Kidney } \\
\text { Disease Stages }\end{array}$ & Description & Potential Sign/Symptoms \\
\hline Stages 1 and 2 & $\begin{array}{c}\text { minimal kidney damage with normal eGFR } \\
>60 \mathrm{~mL} / \mathrm{min} / 1.73 \mathrm{~m}^{2}, \mathrm{ACR} \geq 30 \mathrm{mg} / \mathrm{g}\end{array}$ & $\begin{array}{c}\text { usually urea and creatinine levels are normal } \\
\text { or slightly raised }\end{array}$ \\
\hline Stage 3 & moderate reduced eGFR $30-59 \mathrm{~mL} / \mathrm{min} / 1.73 \mathrm{~m}^{2}$ & $\begin{array}{c}\text { early signs occur and may comprise fatigue } \\
\text { and weakness, loss of appetite, itching, rising } \\
\text { levels of urea and creatinine, anemia, nausea, } \\
\text { vomiting, hypertension }\end{array}$ \\
\hline Stage 4 & severe reduced eGFR $15-29 \mathrm{~mL} / \mathrm{min} / 1.73 \mathrm{~m}^{2}$ & $\begin{array}{c}\text { anemia, hypertension, nausea, vomiting, } \\
\text { reduction in calcium absorption, } \\
\text { dyslipidemia, heart failure, metabolic acidosis }\end{array}$ \\
\hline Stage 5 & kidney failure, eGFR $<15 \mathrm{~mL} / \mathrm{min} / 1.73 \mathrm{~m}^{2}$ & $\begin{array}{c}\text { anemia, hypertension, nausea, vomiting } \\
\text { hypertrophy of left ventricular, } \\
\text { hyperparathyroidism, hyperphosphatemia, } \\
\text { hyperkalemia }\end{array}$ \\
\hline $\begin{array}{c}\text { End-stage renal } \\
\text { disease (ESRD) }\end{array}$ & renal transplant and dialysis & $\begin{array}{c}\text { Anemia, cardiovascular dysfunction, } \\
\text { hyperparathyroidism, hyperphosphatemia, } \\
\text { hyperkalemia }\end{array}$ \\
\hline
\end{tabular}

eGFR estimated glomerular filtration rate; ESRD, end-stage renal disease, ACR, albumin: creatinine ratio.

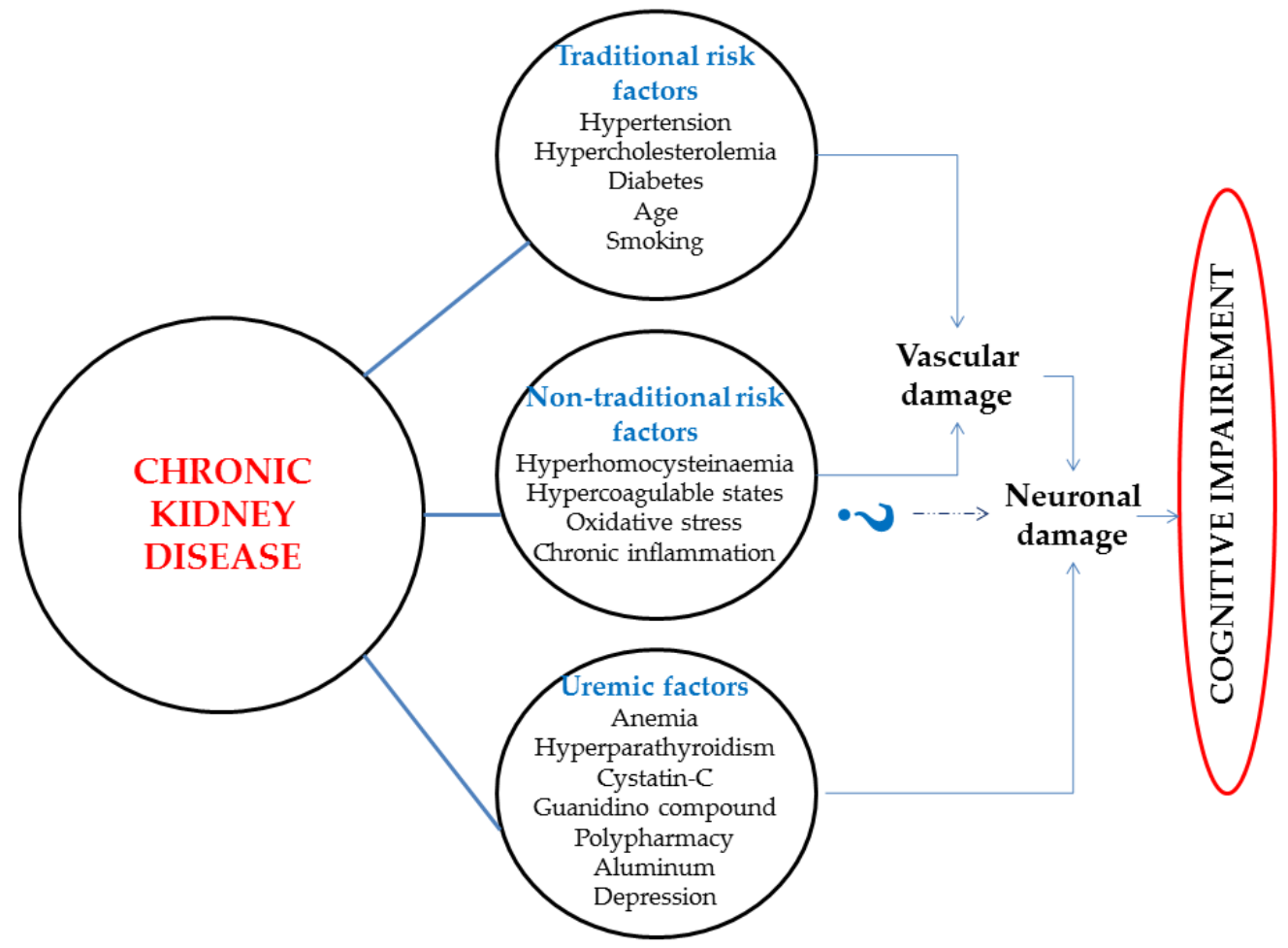

Figure 1. Factors linking chronic kidney disease and Alzheimer's disease.

CKD stimulates the development of cognitive decline and the progression of AD [25], which can prove to be an expediency but also a challenge in the early diagnosis and therapy of this chronic irreversible condition; additionally, the prevalence of CKD is constantly increasing. In the first multicenter study on CKD in China, Zhang et al. [8] reported an increase in AD of up to $10.8 \%$ in 50,550 CKD individuals, a rate that has shown an upward tendency year by year.

To date, the pathophysiology of $\mathrm{AD}$ and the role of CKD in AD progression are not completely known. As effective pharmacotherapies of AD remain limited [37-39], studies based on the prevention 
against major, modifiable risk factors will matter more and more. In the current review, we sought to provide an overview of prevalence, socio-economic aspects, and links between CKD and AD. Furthermore, we highlight the present understanding of the mechanisms for cognitive decline in patients with these concurrent pathologies and provide insight into the relationship between markers related to $\mathrm{AD}$ and $\mathrm{CKD}$ and whether the potential biomarkers for renal function may be used for the diagnosis of Alzheimer's disease. Detailed exploration of knowledge about the molecular link between these conditions opens new windows for diagnosis and treatment, the development of biomarkers, or the validation of whether the setting of CKD could be a possible new element for cognitive damage in AD.

\section{The Mechanisms Proposed for Cognitive Decline and Alzheimer's Disease Associated with Chronic Kidney Disease}

Despite the recognized association between cognitive conditions and renal failure, direct evidence connecting brain injury to CKD is still absent. In this context, various hypotheses have been designed as supplementary pathways for kidney-brain communication, comprising renin-angiotensin system, oxidative stress, vascular injury, and inflammation [40]. It is worth noting that the crosstalk between kidney and brain appears to be bidirectional, as conditions of the central nervous system, such as traumatic brain injury and migraine, are independent risk factors for CKD as well [41,42].

\subsection{Vascular Dysfunction}

From a pathophysiological point of view, it is known that AD may have a vascular constituent, and the cause of cognitive decline is multifaceted. In difference, individuals with CKD are expected to present a disproportionate degree of cerebrovascular disease (CVD), mostly small-vessel CVD, which might be a significant cause in the development and evolution of CKD-associated cognitive decline $[43,44]$. This theory is based on the fact that secondary neuropsychiatric disorders occurring in patients with renal lesions might be due to the hemodynamic relations between the kidney and the brain, CKD being acknowledged as an important cause for vascular dementia and stroke [45,46]. Vascular cognitive deficits or mixed vascular dysfunction and AD appear to have a much higher incidence in hemodialysis individuals than AD alone $[47,48]$. Therefore, there is a robust likelihood that CKD patients are at an elevated risk for cognitive decline determined by vascular-associated causes, expressed as brain microinfarcts and white matter disease, and not overt AD per se [49]. The cerebral vascular condition seems to act concurrently with a neurodegenerative mechanism partially facilitated by uremic toxins, homocysteine, cystatin $C$, and/or creatinine levels [50]. The cognitive damage reported in cerebrovascular conditions mostly influences processing speed, and executive functioning, and cognitive areas that influence planning and carry out a task, and the majority of findings have shown that executive function and processing are the domains most affected in CKD patients [51,52]. Finally, cognitive decline leads to worse emotional well-being and quality of life [53]. Reduction in renal function has been correlated with deficient cerebral white matter integrity, and the presence of albuminuria has been correlated with a diminution of glomerular filtration rate (GFR) and lower brain-blood flow [54]. As the renal function decreases in the patients with CKD, the cognitive performance worsens, but it may be improved by kidney transplant. Several longitudinal studies showed an improvement of cognitive function after transplantation, an effect explained by the fact that, following transplant, the essential functions of the kidneys may be restored on one side, and on the other side, transplantation eliminates the need for hemodialysis, which might induce cognitive impairment because of hemodynamic changes [55-59]. Other studies have investigated patients with CKD undergoing peritoneal dialysis or hemodialysis or patients proposed for transplant whose cognitive performance was lower compared to patients without CKD [60]. During the dialysis process due to large changes and hemodynamic alterations that occur, there is a risk of increased acute cognitive impairment by the occurrence of acute cerebral ischemia [59]. Regarding the pathophysiology of cognitive decline in hemodialysis patients, systemic microvascular disease determined by inflammatory 
elements, hypertension, or diabetes, involving both the cerebral and renal area, could be a potential shared mechanism for the two conditions [61]. At the renal level, the degree of microvascular damage and the occurrence of microalbuminuria secondary to kidney injury may reveal comparable cerebral microvascular damage by disturbing the blood-brain barrier, the impairment of which causes protein leakage with cerebral white matter disease. This has been supported by brain imaging studies, which showed that progression of $\mathrm{AD}$ is enhanced in individuals with increased cerebro-spinal fluid/plasma albumin ratio [62,63].

Vascular stiffness well-defined as reduced vascular elasticity and prolongation of the duration of expansion of blood vessel as well as calcification expressed as significant deposition of calcium in the vascular wall are common traits of CVD [64]. Vascular stiffness is detected in the evolution of CKD and is substantially related with cognitive dysfunction [65]. Remarkably, vascular stiffness and impaired renal functions are strongly related to AD, whereby a vascular mechanism is largely implicated in the pathological processes of AD in CKD cases [66]. Moreover, a linkage between the renal function impairment and cognitive decline could be supported by the fact that the erythropoietin mainly synthetized at a renal level has neuroprotective effects, and its low levels reported in renal impairment, particularly in patients with renal insufficiency, may contribute to cognitive decline $[67,68]$.

The endothelial interface, a synthetic bioreactor that generates various soluble factors, appears to be substantially functionally modified in neurodegenerative diseases, promoting a harmful central nervous system (CNS) environment by distributing neurotoxic and inflammatory species [69]. Markers of endothelial activation (EA) and dysfunction, such as plasma levels of von Willebrand factor (vWF), soluble vascular cell adhesion molecule-1 (sVCAM-1), soluble intercellular cell adhesion molecule-1 (sICAM-1), and sE-selectin were associated with reduced executive functioning and information processing speed in older subjects without [70] or with late-onset AD or vascular dementia [71]. The results of these studies, in addition to the vascular hypothesis, support the idea that elevated levels of EA markers are primarily implicated in the pathogenesis leading to cognitive decline [72].

\subsection{Inflammation and Oxidative Stress}

As the CNS immune system might be impaired by the inflammatory processes, the brain function can also be modulated by various mediators, such as pro-inflammatory cytokines, interleukines- $1 \beta$ (IL-1 $\beta$ ), and the tumor necrosis factor (TNF), which may pass the blood-brain barrier (BBB) leading to neuropsychiatric alterations [40]. In patients with CKD, the concentrations of these cytokines, as well as elevated pro-inflammatory enzymes, such as inducible nitric oxide synthase (iNOS) and cyclooxygenase-2 (COX-2), appear to be positively controlled by the activation of nuclear-factor kappa-light-chain enhancer of activated B cells (NF-kB) [73]. The evidence of communication between the periphery and the CNS is the sickness behavior defined by behavioral changes, including neuropsychiatric developed in sick persons during inflammatory processes in the body [74]. Inappropriate and sustained activation of the innate immune system might be implicated in several neurologic diseases, among which is AD. The latest results of cytokine actions in the brain offer certain clues about the physiopathology of precise CNS disorders [75]. The potential mechanisms of kidney-brain crosstalk regarding inflammatory molecules are based on the fact that cytokines, such as IL-1 $\beta$, interleukine-6 (IL-6), the TNF, and transforming growth factor $\beta$ (TGF- $\beta$ ) frequently involved in the pathogenesis of CKD, may influence remote organs, such as the brain, reinforcing the idea of a kidney-brain inflammatory crosstalk $[40,76]$.

Another important aspect related to the inflammatory theory is the oxidative stress defined to be the consequence of the imbalance between the oxidant system (production of free radicals) and antioxidant system, in favor of the oxidants, with destructive and pathogenic potential by disruption of proteins, lipids, and nucleic acids, with function losses and apoptosis [77], and other studies have shown that oxidative stress is related to the onset and development of diverse diseases like CKD and neurodegenerative disorders $[40,78]$. Various studies reported a reverse relationship between markers of oxidative stress and the filtration rate, which suggests that as the renal function is impaired, 
the species of free radicals gradually increase [78]. The pathogenesis of the oxidative stress in patients with kidney disorders is exhaustive, uremia and dialysis being among the important and frequent factors. As the renal function decreases, the antioxidant enzymes are modified, particularly in uremic patients. An increase in oxidative stress levels during hemodialysis might be due to the dialysis membrane and to the quantity of endotoxin during dialysis [54,74]. In CKD patients, excessive increase in reactive oxygen species (ROS) was linked to the inflammatory processes as the presence of endogenous oxidants and uremic toxins in the plasma may be a source of oxidative stress (Figure 2) [75]. In fact, reduction in nitric oxide bioavailability initiated by endothelial activation and dysfunction caused by oxidative stress stimulates the development of atherosclerosis. Increased ROS causes the inactivation and lack of nitric oxide, which is a key antioxidant in the protection of renal function by growing kidney blood flow, increasing natriuretic pressure, controlling tubule-glomerular activity, and maintaining electrolyte and fluid homeostasis. Deficiency of nitric oxide and elevated levels of plasma superoxide anion are suggested as essential promotors of oxidative stress [79]. A clinical study conducted by Vinothkumar et al. [80] determined the A $\beta$ level in plasma in CKD and cognitive dysfunction patients. A total of 60 CKD patients, 30 CKD plus cognitive dysfunction patients and 30 control patients were included. The results of the study showed that enzymatic parameters, such as superoxide-dismutase (SOD), glutathione-peroxidase (GPX), catalase (CAT), and reduced glutathione (GSH), reported decreased levels in plasma and the lipoperoxidation level (LPX) being significantly increased in CKD plus cognitive dysfunction patients [80]. The LPX is a normal metabolic process in the life of a cell, but the excess is a pathogenic factor involved in more vascular and degenerative disorders. Counteracting the action of the oxygen-derived free radicals, which attack membrane phospholipids and initiate lipoperoxidation, both physiologically and pathologically, the body has a complex modulating and protective system, with an enzymatic component (SOD, GPX, GTP, CAT) and a non-enzymatic component (vitamin C, vitamin E etc.) [76]. In AD, an overexpression of the gene codifying SOD as well as in trisomy 21 was found. This enzyme is harmful due to the production of hydrogen peroxide, with the formation of superoxide ion. Based on the observations on $A \beta$ peptide and on the role of free radicals in AD, Rose [81,82] showed that the formation of a A $\beta$ peptide-ApoE complex might be favored by the presence of free radicals, and Buttefield et al. [83] showed that $\mathrm{A} \beta$ peptide in water solutions fragmentizes and generates free-radical peptides. This model could explain the slow onset of the disease: young people with higher antioxidant capabilities have a higher endurance to stress caused by free radicals, while aging associated with environmental stressors and genetic anomalies create favorable conditions for the onset of AD [74,83].

The evolution and severity of CKD are intensely related with the amplification of oxidative stress and inflammatory condition. These are recognized as risk factors for the onset of different systemic complications, such as cardiovascular disorders, mineral diseases, or anemia. Biological mechanisms comprising xanthine oxidase, mitochondrial activity, and nicotinamide adenine dinucleotide phosphate hydrogen oxidase appear to contribute to the onset and exacerbation of oxidative stress and inflammation [84]. 


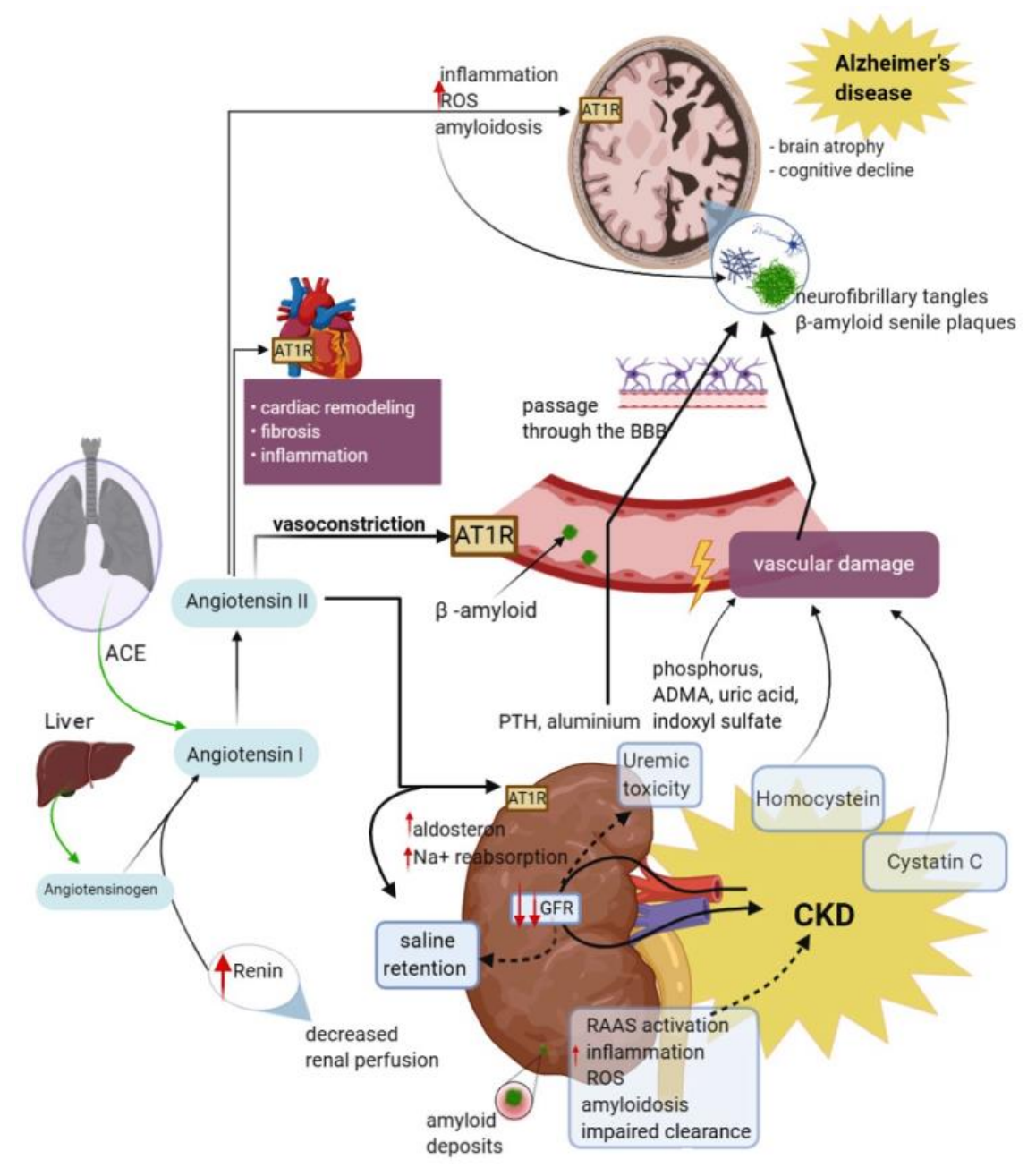

Figure 2. Schematic representation of mechanisms implicated in cognitive decline and AD in CKD patients, comprising renin-angiotensin system, oxidative stress, vascular injury, and inflammation. Diminished glomerular filtration rate and renal perfusion affect renal clearance. Renal retention of oxidizing substances promotes the intensification of oxidative stress and inflammation, which together with a defective clearance, causes an increase in plasma concentrations of uremic toxins, homocysteine, Cystatin C, amyloid deposits, and other molecules. These substances exert their toxic action through various mechanisms. Low renal perfusion leads to increased renin synthesis, and in its presence, the angiotensinogen synthesized in the liver is transformed into angiotensin I, which in turn, in the presence of angiotensin converting enzyme passes into angiotensin II. Angiotensin II activates AT1 receptors and produces hydro-saline retention, cardiac remodeling, vasoconstriction, and the development of $\beta$-amyloid deposits. The consequences of kidney damage are also reflected in the vascular and cerebral level with the aggravation of the cognitive deficit present in AD. The potential mechanisms of kidney-brain crosstalk regarding inflammatory molecules are because cytokines frequently involved in the pathogenesis of CKD may influence remote organs, such as the brain. The pathogenesis of the oxidative stress in patients with CKD is exhaustive, uremia and dialysis being among the important and frequent factors. Moreover, in these patients, an excessive increase in ROS was linked to the inflammatory processes, as the presence of endogenous oxidants and uremic toxins in the plasma may be a source of oxidative stress. Nevertheless, vascular damage and the direct neurotoxicity of uremic toxins produced by renal altered function are the most reasonable pathways of the effects of CKD in AD patients. AD, Alzheimer's disease; ANG I, angiotensin I; ANG II, angiotensin II; $\mathrm{ACE}$, angiotensin converting enzyme; RAAS, renin-angiotensin-aldosterone system; BBB, blood-brain barrier; GFR, glomerular filtration rate; AT1R, angiotensin II receptor type 1; ROS, reactive oxygen species; $\mathrm{Na}$, sodium; ADMA, asymmetric dimethylarginine; $\mathrm{CKD}$, chronic kidney disease. 


\subsection{The Renin-Angiotensin-Aldosterone System (RAAS)}

The renin-angiotensin-aldosterone system (RAAS) is an endocrine system widely known for its physiological roles in electrolyte homeostasis, body fluid volume regulation, and cardiovascular control [85], with renin and angiotensin being critical factors [86]. Renin, an enzyme produced by the kidney, acts on angiotensinogen (AGT), a liver-precursor, transforming it into angiotensin I (ANGI), a decapeptide. The levels in plasma of the angiotensinogen may be increased by high levels of corticosteroids and other hormones. Another enzyme, angiotensin converting enzyme (ACE), cleaves ANG I to the active octapeptide ANG II, predominant at lung, heart, cardiac, renal, adrenal, and brain level, with a variety of functions, such as vasoactive on all blood vessels; stimulation of adrenal glands with aldosterone release involved in maintaining sodium-potassium homeostasis by stimulation of proximal tubules; stimulation of antidiuretic hormone (ADH), as well as playing a role in the cognitive processes (memory and learning) (Figure 2) [85-88]. ANG II may influence the release of prostaglandins with the occurrence of renal vasoconstriction. ANG II degradation with ACE enzyme is the basis of treating diabetic nephropathy, and its deficit has been associated with albuminuria and glomerular injury. Use of angiotensin converting enzyme inhibitors and angiotensin II receptor blockers together with a low sodium intake proved to have beneficial effects on renal pathology [87].

RAAS activation also mediates brain level effects, such as neuronal damages, as this system is expressed in the CNS. ANG II, the key element of the system also mediates the progression of AD [86]. Discovery of the RAAS independent of the peripheral system encouraged several investigators to focus on this system with implications in the brain function and disorders and in neuroprotection but with possible roles in the etiology of the AD as well. An important factor in AD pathology is the chronic stress facilitating the increase in brain ANG II level; a tight relationship between ANG II increased levels and amyloidgenesis has been suggested. This hypothesis has been consolidated by various recent studies that reported the beneficial effects on the cognitive processes or even the diminishing of $\mathrm{A} \beta$ oligomerization on $\mathrm{AD}$ animal models, following treatment with angiotensin II receptor blockers $[85,89]$. The chronic activation of RAAS followed by the increase in ANG II level and activation of angiotensin II receptor type 1 may lead to the occurrence of various physiopathological processes, such as vasoconstriction, inflammation, high sodium renal intake, and fibrosis. Similarly, it has been found that all the components of the brain renin-angiotensin system may be synthesized locally in the brain. More studies reported that both renin and angiotensinogen have been detected in brain cells, stimulating renin signaling and determining cognitive impairment by activation of angiotensin receptors [90]. RAAS receptors have been observed in several brain areas, including the hippocampus and the cingulate cortex [91]. In the brain, angiotensin II type 2 receptor activation contributes to the control of the cerebral circulation, central sympathetic activity, integrity of the BBB, and the regulation of the brain's innate immune response [92]. Brain over-activation of angiotensin II receptors is associated with pathological processes, including inflammation and cognitive decline, as it occurs in $\mathrm{AD}$ [93]. The brain renin-angiotensin system might be a risk factor for oxidative stress, which mediates the brain function as increased ANG II stimulates superoxide generation by inflamed cells causing death of dopaminergic neurons [85].

The relationship between cognitive decline and impaired kidney function appears to be bidirectional. Understanding the pathology of the relations between these two conditions is essential to preclude and/or reduce the incidence and influence of cognitive damage in CKD patients.

\section{The Relationship between Biomarkers Related to Alzheimer's Disease and Renal Function}

\subsection{The Potential Pathophysiological Markers Associated to Alzheimer's Disease}

Pathologically, $\mathrm{AD}$ is characterized by the accumulation of $\mathrm{A} \beta$ peptides, visualized as senile plaques and hyper-phosphorylated Tau proteins, which appear as neurofibrillary tangles located in the neocortex and the hippocampus [2]. The intracellular neurofibrillary tangles are composed of paired helical filaments formed of hyper-phosphorylated Tau protein aggregates, and the senile plaques are 
rich in $A \beta$, which can be secreted by neurons directly into the cerebro-spinal fluid (CSF) [94]. A $\beta$ is a peptide formed of $40-42$ amino acids, with a molecular weight of approximatively $4 \mathrm{kDa}$, that is derived from the proteolytic cleavage of APP by the action of $\beta$ and $\gamma$-secretases [83,95]. It is worth mentioning that, elevated serum $A \beta$ levels were also recorded in CKD individuals, probably due to the reduced clearance of $A \beta$ protein overproduction in the blood of these patients, leading to the idea that cognitive damage and $A D$ related to impaired renal function may be influenced by $A \beta$ protein in people with CKD [96]. Moreover, in recent years, more studies support that the CSF A $\beta 1-40 / A \beta 1-42$ levels are better predictors of $\mathrm{AD}$ progression than plasma $\mathrm{A} \beta$ isoforms $[94,97]$. Clinico-pathological correlation studies have revealed that a growth in tau protein/phosphorylated tau in the CSF represents a sign of AD and correlates with the degree of dementia [98,99]. Furthermore, studies revealed that changes in the $A \beta$ deposition and tau protein can be linked to the AD pathology after the increase in aluminum in dialysis patients [100].

Homocysteine (Hcy), a key molecule formed during the metabolism of sulfur-containing amino acids, is a direct and modifiable risk factor of early cognitive impairment, being involved in AD pathogenesis $[101,102]$ through the dysfunction of endothelial cells and small blood vessels by oxidative stress $[4,103]$. Hyperhomocysteinemia, a condition of high levels of Hcy in the blood, is a frequent clinical finding in patients with CKD or acute kidney injury (AKI), probably due to impaired Hcy clearance in individuals with renal impairment $[104,105]$. The increase in Hcy levels determined by CKD has been correlated to the decrease in A $\beta 1-42$ in the CSF, suggesting that serum Hcy levels may be a potential marker of $\mathrm{AD}$ in CKD patients [97].

Recent advances in blood biomarkers of cognitive dysfunction have demonstrated that Glycogen synthase kinase- $3 \beta$ (GSK3 $\beta$ ), a serine/threonine kinase, plays a notable role in the AD pathogenesis. Excessive activation of GSK3 $\beta$ is accompanied by A $\beta$ production and hyper phosphorylated tau [106]. The relationship between GSK-3 $\beta$, total tau, $p$-Tau 181 levels, $A \beta$ and neurodegeneration, investigated mostly in cases with mild cognitive dysfunction $[107,108]$ or mild AD, reflects a robust negative correlation between abnormal proteins concentrations with the Mini Mental State Exam and Wechsler Memory Scale-I and a positive one with Tower of London test [109]. Detection and use of uncharacteristic protein levels, preferable in relation to neuropsychological screening, appear to be a possible instrument that may improve the CKD in connection with cognitive decline diagnosis. Several other blood biomarkers of AD cognitive decline have been suggested. Increased plasma neurofilament light chain (NfL) concentrations are highly correlated with cerebrospinal fluid levels [110], which might be comparable in relation to diagnostic efficiency with $A \beta 1-42: A \beta 1-40$ plasma ratio [111]. Stevenson et al. [112] pointed out that the intrinsic pathophysiological features of dementia, including $\mathrm{AD}$, can be reflected by erythrocytes. Furthermore, the authors also suggested that the morphology of erythrocyte and their protein levels, such as calpain-1, Hsp90, and IgG A, were relevant blood biomarkers for AD. Plasma evaluation of over 50 categories of inflammatory proteins in individuals with cognitive decline and compared them with healthy controls revealed that $\mathrm{FH}$ (factor $\mathrm{H}$ ) and FB (factor B) could predict the evolution of mild cognitive impairment to AD [113]. However, the specificity of these blood biomarkers of AD cognitive dysfunction has not been rigorously studied, and they remain frequently in the discovery phase of development. Elevated plasma levels of $\alpha 1$-antichymotrypsin have been validated in $\mathrm{AD}$ with fluctuating degrees of correlation to disease progression [114], but this result was not sustained by a third study [115].

\subsection{Potential Use in the Diagnosis of Alzheimer's Disease of the Biomarkers Associated with Chronic Kidney Disease}

A review of the existing data regarding uremic toxicity identified more than 90 different types of urinary toxins in CKD individuals, however their impact on the body remains unclear [116]. Low kidney perfusion and severe GFR reduction are the most frequent reasons for increased and accumulated uremic toxins in CKD cases. Lately, increased attention has been focused on small and intermediate-sized molecule toxins, such as phosphorus, parathyroid hormone (PTH), asymmetric dimethylarginine 
(ADMA), uric acid, indoxyl sulfate, and aluminum $[117,118]$. Recent studies have shown a substantial elevation in PTH levels in CKD patients' blood, and this hormone is closely associated with a cognitive decline and AD [119-122]. Given the ability of PTH to cross the BBB and the receptors for this hormone being disseminated in the brain, a parathyroidectomy performed in CKD patients with secondary hyperparathyroidism may attenuate the cognitive impairment [123]. The mechanisms proposed to elucidate the possible links between PTH, cognitive damage, and AD include the role of PTH in regulation of intra- and extracellular calcium and decrease local brain blood flow by increased the concentration levels of PTH [123-125]. In addition, ADMA and hyperphosphatemia have been confirmed to be involved in the development of renal failure and vascular injury [126-128]. Hyperuricemia, a mediator or an independent risk factor for the development and progression of renal disease, is closely associated with brain atrophy and memory decline in CKD [129,130]. Pathophysiological mechanisms underlying these effects initiated by uric acid are an activation of RAAS, augmented oxidative stress, endothelial dysfunction, proinflammatory, and proliferative actions $[131,132]$. In CKD, the reduced capacity to remove protein-binding agents, such as indoxyl sulfate, can promote inflammatory genes expression and oxidative stress, leading to cognitive dysfunction $[133,134]$. Moreover, indoxyl sulfate causes inflammation, amplifying the interaction between endothelial cells and leukocyte, which is notable in the AD development [135]. Elevated brain deposits of aluminum caused dementia in dialysis patients [54] and are correlated with high mortality rates. The complications described in response to exposure to aluminum-containing phosphate binders or to water used in dialysis preparations containing high levels of aluminum could be eliminated by strict water tests and limiting the use of aluminum-based phosphorus binders $[136,137]$.

Cystatin C, another marker of kidney function appears to be less influenced by muscle mass, being an important predictor of clinical results linked to AKI and CKD than creatinine, although its clinical role is not yet clearly defined $[138,139]$. The co-localization of cystatin C, a protein encoded by the CST3 gene, a sensitive gene of late-onset $\mathrm{AD}$ with $\mathrm{A} \beta$ in parenchymal and vascular amyloid deposits in the brains of individuals with AD, may reveal cystatin C contribution in amyloidogenesis [140,141]. Recent studies have highlighted that cystatin $C$ shows a controversial influence in the pathology of $\mathrm{AD}$; on the one hand, it appears to control the levels of $\mathrm{A} \beta$ that bind directly to $\mathrm{A} \beta$ and inhibit its aggregation, but on the other hand, as a substrate for cathepsin $B$ protease, it appears to be competitive for $A \beta$ degradation [142-144]. To date, it is not known whether cystatin $C$ brain deposition leads to a reduction in cystatin $C$ in peripheral plasma or whether in patients with CKD increased plasma cystatin $C$ concentrations would stimulate precipitation and binding of cystatin $C$ and APP in the brain. Serum cystatin C levels may be a novel possible biomarker of AD in CKD people. Additionally, proteinuria and eGFR are recognized as common indicators for renal function $[145,146]$ are closely associated to a cognitive decline $[25,36]$.

\section{Effects of Renal Replacement Therapies on Amyloid-Beta Pathology}

As AD still remains irreversible, studies continue to explore modifiable risk factors as a promising safe approach for AD prevention and therapy, which could lead to the avoidance of side effects related with the entry of $A \beta$-targeted compounds into the brain. To date, restoring the function of $A \beta$ clearance is considered a valuable strategy for treating $A D$ [147]. It has been shown that elevated $A \beta$ production or deficits in $A \beta$ clearance play key or causal roles in the pathogenesis of $\mathrm{AD}$. In patients diagnosed with $\mathrm{AD}, \mathrm{A} \beta$ clearance via the $\mathrm{BBB}$ was estimated to be decreased by approximately $30 \%$ [148]. Despite previous studies on murine and human BBB models that have highlighted that about $40-60 \%$ of brain-derived $A \beta$ is cleared in the periphery, the amount and mechanisms are still poorly understood $[149,150]$. Deep cervical lymph node ligation intensified AD-like pathology in APP/PS1 mice exhibiting more severe cerebral A $\beta$ deposition, synaptic protein loss, neuroinflammation, decreased polarization of aquaporin-4, and exploratory and cognitive behaviors deficits [151]. Jin et al. [152] in a clearance of brain-derived $A \beta$ study found that peritoneal dialysis, a clinically existing therapeutic method for $C K D$, significantly reduced $A \beta$ deposition, also attenuating 
other AD-type pathologies, such as neuroinflammation, tau hyperphosphorylation, glial activation, synaptic dysfunction, and neuronal loss and attenuated the behavioral impairment in APPswe/PS1 mice.

Liu et al. [153], in a study on the potential implications of renal roles in A $\beta$ clearance, revealed that serum $A \beta 1-40$ and $A \beta 1-42$ levels measured were significantly higher in CKD patients (31 dialyses cases and 16 non-dialyses individuals) than in healthy control subjects. Moreover, CKD individuals receiving peritoneal dialysis registered inferior levels of $A \beta$ than non-dialysis cases, being comparable to those of healthy controls and have been correlated with renal function as evaluated by eGFR and residual GFR. The cause of these higher concentrations of $A \beta$ in patients with renal dysfunction without dialysis is not fully known. These results sustain the main role of kidney in $A \beta$ hemostasis and the idea that impaired renal function could lead to inadequate $A \beta$ clearance and thus contribute to the AD development $[154,155]$.

A prospective study on plasma $A \beta$ levels and cognitive function on CKD patients performed during the period between baseline and long-time hemodialysis (18 or 36 months) showed that A $\beta 1-40$ levels diminished or did not change, while A $\beta 1-42$ levels remained unchanged or tended to increase significantly at the second time point. In most patients without broad cerebral white matter modifications, Mini Mental State Examination scores elevated or were maintained at 18 months follow-up. These findings suggest that cognitive decline as a consequence of cerebrovascular disease has not been improved by hemodialysis [156]. A rapid decrease in the blood of $A \beta$ concentrations can act as a trigger to increase $A \beta$ excretion from the brain, leading to attenuation of the cognitive decline. Thus, previous studies using a kinetic analysis described that hemodialyzers were able to reduce $A \beta 1-42$ and $A \beta 1-40$ by $32.7 \%$ and $51.1 \%$, respectively, inducing an extensive influx of $A \beta$ into the blood during hemodialysis periods $[157,158]$. In contrast, elevated blood $A \beta$ levels and impaired cognitive performance along with decreased renal function in CKD patients without hemodialysis [158].

In a similar study by Tholen et al. [159], assessing cognition and plasma A $\beta$ concentrations in cognitively impaired hemodialysis patients, the total clearance rates of plasma $A \beta 1-40$ and $A \beta 1-42$ were about $35 \%$ and $28 \%$, respectively, with a significant reduction in the first 2 hours of hemodialysis. Moreover, $A \beta 1-42$, not $A \beta 1-40$, baseline levels were significantly correlated with cognitive function using the Montreal Cognitive Assessment. In line with these results, renal clearance of $A \beta$ could be vital in maintaining cognitive performance and peripheral $A \beta$ decrease by hemodialysis and, in the future, could serve as an anti-amyloid therapy strategy, despite its usefulness in AD patients.

\section{Conclusions}

The pathophysiology and neuropathological substrates shared by brain and kidney damage are robust and complex. The cognitive decline and $\mathrm{AD}$ registered in CKD patients may be explained by the susceptibility of brain tissue to vascular dysfunction, inflammation, oxidative stress, and the renin-angiotensin-aldosterone system. Prompt recognition and management of these mechanisms in first CKD stages may signify a window of opportunity to diminish their influence at advanced stages. Increasingly detailed exploration of the molecular relationship between renal failure and brain function, as a shared pathological feature in both $\mathrm{CKD}$ and $\mathrm{AD}$, is crucial in order to diminish the risk for future cognitive deficits and may provide new directions for development of therapies and biomarkers that can preclude or diminish the occurrence of CKD, as well as AD. Additionally, the setting of renal impairment could be evaluated as a potential determinant for cognitive damage in Alzheimer's disease. We could acquire surprising findings if we center our attention on alterations that occur in both the kidneys and the brain in additional research in the prevention and therapy of $\mathrm{AD}$ and CKD.

Author Contributions: Conceptualization, G.D.S.; writing-original draft preparation, G.D.S., D.C.A., V.B., M.M.G., and L.P.; writing-review and editing, W.B. and B.-I.T.; supervision, B.-I.T., project administration, G.D.S.; funding acquisition, M.M.G. All authors have read and agreed to the published version of the manuscript.

Funding: This research was funded by “Grigore T. Popa” University of Medicine and Pharmacy Iasi, grant number 30337/28.12.2017. 
Conflicts of Interest: The authors declare no conflict of interest. The funders had no role in the design of the study; in the collection, analyses, or interpretation of data; in the writing of the manuscript, or in the decision to publish the results.

\section{Abbreviations}

\begin{tabular}{|c|c|}
\hline $\mathrm{AD}$ & Alzheimer's disease \\
\hline APP & amyloid precursor proteins \\
\hline CKD & chronic kidney disease \\
\hline ApoE4 & epsilon 4 allele of the apolipoprotein E gene \\
\hline SorLA & sorting protein-related receptor \\
\hline eGFR & estimated glomerular filtration rate \\
\hline ESRD & end-stage renal disease \\
\hline CVD & cerebrovascular disease \\
\hline IL-1 $\beta$ & interleukines- $1 \beta$ \\
\hline IL-6 & interleukine-6 \\
\hline TNF & tumor necrosis factor \\
\hline BBB & blood brain barrier \\
\hline CNS & central nervous system \\
\hline TGF- $\beta$ & transforming growth factor $\beta$ \\
\hline ROS & reactive oxygen species \\
\hline SOD & superoxide-dismutase \\
\hline GPX & glutathione-peroxidase \\
\hline CAT & catalase \\
\hline GSH & glutathione \\
\hline LPX & lipoperoxidation level \\
\hline RAAS & renin-angiotensin-aldosterone system \\
\hline AGT & angiotensinogen \\
\hline ANG I, II & angiotensin I, II \\
\hline$A \beta$ & beta-amyloid \\
\hline ACE & angiotensin converting enzyme \\
\hline $\mathrm{ADH}$ & antidiuretic hormone \\
\hline Hcy & homocysteine \\
\hline PTH & parathyroid hormone \\
\hline ADMA & asymmetric dimethylarginine \\
\hline RAAS & renin-angiotensin-aldosterone system \\
\hline vWF & von Willebrand factor \\
\hline sVCAM-1 & soluble vascular cell adhesion molecule-1 \\
\hline sICAM-1 & soluble intercellular cell adhesion molecule- 1 \\
\hline EA & endothelial activation \\
\hline GSK3 $\beta$ & glycogen synthase kinase- $3 \beta$ \\
\hline NfL & neurofilament light chain \\
\hline $\mathrm{FH}$ & factor $\mathrm{H}$ \\
\hline FB & factor B \\
\hline iNOS & inducible nitric oxide synthase \\
\hline COX-2 & cyclooxygenase- 2 \\
\hline$N F-\kappa B$ & nuclear factor kappa-light-chain-enhancer of activated B cells. \\
\hline
\end{tabular}

\section{References}

1. Patterson, C. World Alzheimer Report 2018-The State of the Art of Dementia Research: New frontiers; Alzheimer's Disease International: London, UK, 2018.

2. Deture, M.A.; Dickson, D.W. The neuropathological diagnosis of Alzheimer's disease. Mol. Neurodegener. 2019, 5, 1-18. [CrossRef] [PubMed]

3. Wallin, K.; Boström, G.; Kivipelto, M.; Gustafson, Y. Risk factors for incident dementia in the very old. Int. Psychogeriatr. 2013, 25, 1135-1143. [CrossRef] [PubMed] 
4. Baumgart, M.; Snyder, H.M.; Carrillo, M.C.; Fazio, S.; Kim, H.; Johns, H. Summary of the evidence on modifiable risk factors for cognitive decline and dementia: A population-based perspective. Alzheimer's Dement. 2015, 11, 718-726. [CrossRef] [PubMed]

5. Kopp, J.B. Global glomerulosclerosis in primary nephrotic syndrome: Including age as a variable to predict renal outcomes. Kidney Int. 2018, 93, 1043-1044. [CrossRef]

6. Huang, W.; Qiu, C.; Von Strauss, E.; Winblad, B.; Fratiglioni, L. APOE genotype, family history of dementia, and alzheimer disease risk: A 6-year follow-up study. Arch. Neurol. 2004, 61, 1930-1934. [CrossRef]

7. Li, J.; Wang, Y.J.; Zhang, M.; Xu, Z.Q.; Gao, C.Y.; Fang, C.Q.; Yan, J.C.; Zhou, H.D. Vascular risk factors promote conversion from mild cognitive impairment to Alzheimer disease. Neurology 2011, 76, 1485-1491. [CrossRef]

8. Xue, L.; Lou, Y.; Feng, X.; Wang, C.; Ran, Z.; Zhang, X. Prevalence of chronic kidney disease and associated factors among the Chinese population in Taian, China Epidemiology and Health Outcomes. BMC Nephrol. 2014, 15, 205. [CrossRef]

9. Kivipelto, M.; Ngandu, T.; Fratiglioni, L.; Viitanen, M.; Kåreholt, I.; Winblad, B.; Helkala, E.L.; Tuomilehto, J.; Soininen, H.; Nissinen, A. Obesity and vascular risk factors at midlife and the risk of dementia and Alzheimer disease. Arch. Neurol. 2005, 62, 1556-1560. [CrossRef]

10. Forbes, J.M.; Cooper, M.E. Mechanisms of diabetic complications. Physiol. Rev. 2013, 93, 137-188. [CrossRef]

11. Umegaki, H.; Hayashi, T.; Nomura, H.; Yanagawa, M.; Nonogaki, Z.; Nakshima, H.; Kuzuya, M. Cognitive dysfunction: An emerging concept of a new diabetic complication in the elderly. Geriatr. Gerontol. Int. 2013, 13, 28-34. [CrossRef]

12. Kroner, Z. The relationship between Alzheimer's disease and diabetes: Type 3 diabetes? Altern. Med. Rev. 2009, 14, 373-379. [PubMed]

13. Stanciu, G.D.; Bild, V.; Ababei, D.C.; Rusu, R.N.; Cobzaru, A.; Paduraru, L.; Bulea, D. Link Between Diabetes and Alzheimer's Disease due to the Shared Amyloid Aggregation and Deposition Involving both Neurodegenerative Changes and Neurovascular Damages. J. Clin. Med. 2020, 9, 1713. [CrossRef] [PubMed]

14. Reitz, C.; Brayne, C.; Mayeux, R. Epidemiology of Alzheimer disease. Nat. Rev. Neurol. 2011, 7, 137-152. [CrossRef] [PubMed]

15. Wan, J.; Wang, S.; Haynes, K.; Denburg, M.R.; Shin, D.B.; Gelfand, J.M. Risk of moderate to advanced kidney disease in patients with psoriasis: Population based cohort study. BMJ 2013, 347, f5961. [CrossRef]

16. Mayer, F.; Di Pucchio, A.; Lacorte, E.; Bacigalupo, I.; Marzolini, F.; Ferrante, G.; Minardi, V.; Masocco, M.; Canevelli, M.; Di Fiandra, T.; et al. An Estimate of Attributable Cases of Alzheimer Disease and Vascular Dementia due to Modifiable Risk Factors: The Impact of Primary Prevention in Europe and in Italy. Dement. Geriatr. Cogn. Dis. Extra 2018, 8, 60-71. [CrossRef]

17. Qiu, W.Q.; Folstein, M.F. Insulin, insulin-degrading enzyme and amyloid- $\beta$ peptide in Alzheimer's disease: Review and hypothesis. Neurobiol. Aging 2006, 27, 190-198. [CrossRef]

18. Yarbrough, C. Alzheimer's and Kidney Disease: Common Molecular Culprit? Kidney News 2010, 2, 1-5.

19. Wiinow, T.E.; Andersen, O.M. Sorting receptor SORLA-A trafficking path to avoid Alzheimer disease. J. Cell Sci. 2013, 126, 2751-2760.

20. Nielsen, M.S.; Gustafsen, C.; Madsen, P.; Nyengaard, J.R.; Hermey, G.; Bakke, O.; Mari, M.; Schu, P.; Pohlmann, R.; Dennes, A.; et al. Sorting by the Cytoplasmic Domain of the Amyloid Precursor Protein Binding Receptor SorLA. Mol. Cell. Biol. 2007, 27, 6842-6851. [CrossRef]

21. Scherzer, C.R.; Offe, K.; Gearing, M.; Rees, H.D.; Fang, G.; Heilman, C.J.; Schaller, C.; Bujo, H.; Levey, A.I.; Lah, J.J. Loss of apolipoprotein E receptor LR11 in Alzheimer disease. Arch. Neurol. 2004, 61, 1200-1205. [CrossRef]

22. Jacobsen, L.; Madsen, P.; Moestrup, S.K.; Lund, A.H.; Tommerup, N.; Nykjær, A.; Sottrup-Jensen, L.; Gliemann, J.; Petersen, C.M. Molecular characterization of a novel human hybrid-type receptor that binds the a2-macroglobulin receptor-associated protein. J. Biol. Chem. 1996, 271, 31379-31383. [CrossRef] [PubMed]

23. Motoi, Y.; Aizawa, T.; Haga, S.; Nakamura, S.; Namba, Y.; Ikeda, K. Neuronal localization of a novel mosaic apolipoprotein E receptor, LR11, in rat and human brain. Brain Res. 1999, 833, 209-215. [CrossRef]

24. Foundation, N.K. K/DOQI clinical practice guidelines for chronic kidney disease: Evaluation, classification, and stratification. Am. J. Kidney Dis. 2002, 39, S1-S266.

25. Etgen, T.; Chonchol, M.; Frstl, H.; Sander, D. Chronic kidney disease and cognitive impairment: A systematic review and meta-analysis. Am. J. Nephrol. 2012, 35, 474-482. [CrossRef] 
26. Bikbov, B.; Purcell, C.A.; Levey, A.S.; Smith, M.; Abdoli, A.; Abebe, M.; Adebayo, O.M.; Afarideh, M.; Kumar Agarwal, S.; Agudelo-Botero, M.; et al. Global, regional, and national burden of chronic kidney disease, 1990-2017: A systematic analysis for the Global Burden of Disease Study 2017. Lancet 2020, 395, 709-733. [CrossRef]

27. Himmelfarb, J.; Ikizler, T.A. Medical progress: Hemodialysis. N. Engl. J. Med. 2010, 363, 1833-1845. [CrossRef]

28. Liyanage, T.; Ninomiya, T.; Jha, V.; Neal, B.; Patrice, H.M.; Okpechi, I.; Zhao, M.H.; Lv, J.; Garg, A.X.; Knight, J.; et al. Worldwide access to treatment for end-stage kidney disease: A systematic review. Lancet 2015, 385, 1975-1982. [CrossRef]

29. Tonelli, M.; Keech, A.; Shepherd, J.; Sacks, F.; Tonkin, A.; Packard, C.; Pfeffer, M.; Simes, J.; Isles, C.; Furberg, C.; et al. Effect of pravastatin in people with diabetes and chronic kidney disease. J. Am. Soc. Nephrol. 2005, 16, 3748-3754. [CrossRef]

30. Strachan, M.W.J.; Reynolds, R.M.; Marioni, R.E.; Price, J.F. Cognitive function, dementia and type 2 diabetes mellitus in the elderly. Nat. Rev. Endocrinol. 2011, 7, 108-114. [CrossRef]

31. O'Lone, E.; Connors, M.; Masson, P.; Wu, S.; Kelly, P.J.; Gillespie, D.; Parker, D.; Whiteley, W.; Strippoli, G.F.M.; Palmer, S.C.; et al. Cognition in people with end-stage kidney disease treated with hemodialysis: A systematic review and meta-analysis. Am. J. Kidney Dis. 2016, 67, 925-935. [CrossRef]

32. Madero, M.; Gul, A.; Sarnak, M.J. Cognitive function in chronic kidney disease. Semin. Dial. 2008, 21, 29-37. [CrossRef] [PubMed]

33. Tilki, H.E.; Akpolat, T.; Tunali, G.; Kara, A.; Onar, M.K. Effects of haemodialysis and continuous ambulatory peritoneal dialysis on P300 cognitive potentials in uraemic patients. Ups. J. Med. Sci. 2004, 109, 43-48. [CrossRef] [PubMed]

34. Arnold, R.; Krishnan, A.V.; Pussell, B.A. Neurological complications in chronic kidney disease. J. R. Soc. Med. Cardiovasc. Dis. 2016, 5, 1-13. [CrossRef]

35. Tian, X.; Guo, X.; Xia, X.; Yu, H.; Li, X.; Jiang, A.; Zhan, Y. The comparison of cognitive function and risk of dementia in CKD patients under peritoneal dialysis and hemodialysis: A PRISMA-compliant systematic review and meta-analysis. Medicine 2019, 98, e14390. [CrossRef] [PubMed]

36. Kurella Tamura, M.; Wadley, V.; Yaffe, K.; McClure, L.A.; Howard, G.; Go, R.; Allman, R.M.; Warnock, D.G.; McClellan, W. Kidney Function and Cognitive Impairment in US Adults: The Reasons for Geographic and Racial Differences in Stroke (REGARDS) Study. Am. J. Kidney Dis. 2008, 52, 227-234. [CrossRef] [PubMed]

37. Ştefănescu, R.; Stanciu, G.D.; Luca, A.; Caba, I.C.; Tamba, B.I.; Mihai, C.T. Contributions of mass spectrometry to the identification of low molecular weight molecules able to reduce the toxicity of amyloid- $\beta$ peptide to cell cultures and transgenic mouse models of Alzheimer's disease. Molecules 2019, 24, 1167. [CrossRef]

38. Stanciu, G.D.; Luca, A.; Rusu, R.N.; Bild, V.; Chiriac, S.I.B.; Solcan, C.; Bild, W.; Ababei, D.C. Alzheimer's disease pharmacotherapy in relation to cholinergic system involvement. Biomolecules 2020, 10, 40. [CrossRef]

39. Stefanescu, R.; Stanciu, G.D.; Luca, A.; Paduraru, L.; Tamba, B.-I. Secondary metabolites from plants possessing inhibitory properties against beta-amyloid aggregation as revealed by thioflavin-T assay and correlations with investigations on transgenic mouse models of Alzheimer's disease. Biomolecules 2020, 10, 870. [CrossRef]

40. Miranda, A.S.; Cordeiro, T.M.; Soares, T.M.; dos, S.L.; Ferreira, R.N.; Simões e Silva, A.C. Kidney-brain axis inflammatory cross-talk: From bench to bedside. Clin. Sci. 2017, 131, 1093-1105. [CrossRef]

41. Weng, S.-C.; Wu, C.-L.; Kor, C.-T.; Chiu, P.-F.; Wu, M.-J.; Chang, C.-C.; Tarng, D.-C. Migraine and subsequent chronic kidney disease risk: A nationwide population-based cohort study. BMJ Open 2017, 7, 18483. [CrossRef]

42. Wu, C.-L.; Kor, C.-T.; Chiu, P.-F.; Tsai, C.-C.; Lian, I.-B.; Yang, T.-H.; Tarng, D.-C.; Chang, C.-C. Long-term renal outcomes in patients with traumatic brain injury: A nationwide population-based cohort study. PLoS ONE 2017, 12, e0171999. [CrossRef] [PubMed]

43. Santos, C.Y.; Snyder, P.J.; Wu, W.C.; Zhang, M.; Echeverria, A.; Alber, J. Pathophysiologic relationship between Alzheimer's disease, cerebrovascular disease, and cardiovascular risk: A review and synthesis. Alzheimer's Dement. Diagn. Assess. Dis. Monit. 2017, 7, 69-87. [CrossRef] [PubMed]

44. Seliger, S.L.; Gillen, D.L.; Longstreth, W.T.; Kestenbaum, B.; Stehman-Breen, C.O. Elevated risk of stroke among patients with end-stage renal disease. Kidney Int. 2003, 64, 603-609. [CrossRef] [PubMed]

45. Sarnak, M.J.; Tighiouart, H.; Scott, T.M.; Lou, K.V.; Sorensen, E.P.; Giang, L.M.; Drew, D.A.; Shaffi, K.; Strom, J.A.; Singh, A.K.; et al. Frequency of and risk factors for poor cognitive performance in hemodialysis patients. Neurology 2013, 80, 471-480. [CrossRef] 
46. Murray, A.M.; Tupper, D.E.; Knopman, D.S.; Gilbertson, D.T.; Pederson, S.L.; Li, S.; Smith, G.E.; Hochhalter, A.K.; Collins, A.J.; Kane, R.L. Cognitive impairment in hemodialysis patients is common. Neurology 2006, 67, 216-223. [CrossRef] [PubMed]

47. Wardlaw, J.M.; Sandercock, P.A.G.; Dennis, M.S.; Starr, J. Is breakdown of the blood-brain barrier responsible for lacunar stroke, leukoaraiosis, and dementia? Stroke 2003, 34, 806-811. [CrossRef] [PubMed]

48. Wardlaw, J.M.; Lewis, S.C.; Keir, S.L.; Dennis, M.S.; Shenkin, S. Cerebral microbleeds are associated with lacunar stroke defined clinically and radiologically, independently of white matter lesions. Stroke 2006, 37, 2633-2636. [CrossRef]

49. Helmer, C.; Stengel, B.; Metzger, M.; Froissart, M.; Massy, Z.A.; Tzourio, C.; Berr, C.; Dartigues, J.F. Chronic kidney disease, cognitive decline, and incident dementia: The 3C Study. Neurology 2011, 77, 2043-2051. [CrossRef]

50. Bugnicourt, J.M.; Godefroy, O.; Chillon, J.M.; Choukroun, G.; Massy, Z.A. Cognitive disorders and dementia in CKD: The neglected kidney-brain axis. J. Am. Soc. Nephrol. 2013, 24, 353-363. [CrossRef]

51. Weiner, D.E.; Scott, T.M.; Giang, L.M.; Agganis, B.T.; Sorensen, E.P.; Tighiouart, H.; Sarnak, M.J. Cardiovascular disease and cognitive function in maintenance hemodialysis patients. Am. J. Kidney Dis. 2011, 58, 773-781. [CrossRef]

52. Sorensen, E.P.; Sarnak, M.J.; Tighiouart, H.; Scott, T.; Giang, L.M.; Kirkpatrick, B.; Lou, K.; Weiner, D.E. The kidney disease quality of life cognitive function subscale and cognitive performance in maintenance hemodialysis patients. Am. J. Kidney Dis. 2012, 60, 417-426. [CrossRef] [PubMed]

53. Agganis, B.T.; Weiner, D.E.; Giang, L.M.; Scott, T.; Tighiouart, H.; Griffith, J.L.; Sarnak, M.J. Depression and cognitive function in maintenance hemodialysis patients. Am. J. Kidney Dis. 2010, 56, 704-712. [CrossRef] [PubMed]

54. Drew, D.A.; Weiner, D.E.; Sarnak, M.J. Cognitive Impairment in CKD: Pathophysiology, Management, and Prevention. Am. J. Kidney Dis. 2019, 74, 782-790. [CrossRef] [PubMed]

55. Griva, K.; Thompson, D.; Jayasena, D.; Davenport, A.; Harrison, M.; Newman, S.P. Cognitive functioning pre-to post-kidney transplantation-A prospective study. Nephrol. Dial. Transplant. 2006, 21, 3275-3282. [CrossRef] [PubMed]

56. Harciarek, M.; Williamson, J.B.; Biedunkiewicz, B.; Lichodziejewska-Niemierko, M.; Dębska-Slizień, A.; Rutkowski, B. Memory performance in adequately dialyzed patients with end-stage renal disease: Is there an association with coronary artery bypass grafting? J. Clin. Exp. Neuropsychol. 2010, 32, 881-889. [CrossRef] [PubMed]

57. Harciarek, M.; Biedunkiewicz, B.; Lichodziejewska-Niemierko, M.; Debska-Ślizienñ, A.; Rutkowski, B. Cognitive performance before and after kidney transplantation: A prospective controlled study of adequately dialyzed patients with end-stage renal disease. J. Int. Neuropsychol. Soc. 2009, 15, 684-694. [CrossRef] [PubMed]

58. Radić, J.; Ljutić, D.; Radić, M.; Kovaić, V.; Dodig-Ćurković, K.; Šain, M. Kidney transplantation improves cognitive and psychomotor functions in adult hemodialysis patients. Am. J. Nephrol. 2011, 34, 399-406. [CrossRef]

59. Chu, N.M.; Gross, A.L.; Shaffer, A.A.; Haugen, C.E.; Norman, S.P.; Xue, Q.L.; Sharrett, A.R.; Carlson, M.C.; Bandeen-Roche, K.; Segev, D.L.; et al. Frailty and changes in cognitive function after kidney transplantation. J. Am. Soc. Nephrol. 2019, 30, 336-345. [CrossRef]

60. Silva, A.C.S.; Miranda, A.S.; Rocha, N.P.; Teixeira, A.L. Neuropsychiatric disorders in chronic kidney disease. Front. Pharmacol. 2019, 10, 1-11.

61. Kalirao, P.; Pederson, S.; Foley, R.N.; Kolste, A.; Tupper, D.; Zaun, D.; Buot, V.; Murray, A.M. Cognitive impairment in peritoneal dialysis patients. Am. J. Kidney Dis. 2011, 57, 612-620. [CrossRef]

62. Murray, A.M. Cognitive impairment in the aging dialysis and chronic cidney disease populations: An occult burden. Adv. Chronic Kidney Dis. 2009, 15, 123-132. [CrossRef] [PubMed]

63. Naganuma, T.; Takemoto, Y. New aspects of cerebrovascular diseases in dialysis patients. Contrib. Nephrol. 2015, 185, 138-146. [PubMed]

64. Mukai, H.; Svedberg, O.; Lindholm, B.; Dai, L.; Heimbürger, O.; Barany, P.; Anderstam, B.; Stenvinkel, P.; Qureshi, A.R. Skin autofluorescence, arterial stiffness and Framingham risk score as predictors of clinical outcome in chronic kidney disease patients: A cohort study. Nephrol. Dial. Transplant. 2019, 34, 442-448. [CrossRef] [PubMed] 
65. Rabkin, S.W. Is it time to utilize measurement of arterial stiffness to identify and reduce the risk of cognitive impairment? J. Clin. Hypertens. 2018, 20, 31-32. [CrossRef] [PubMed]

66. Oh, Y.S.; Kim, J.S.; Park, J.W.; An, J.Y.; Park, S.K.; Shim, Y.S.; Yang, D.W.; Lee, K.S. Arterial stiffness and impaired renal function in patients with Alzheimer's disease. Neurol. Sci. 2016, 37, 451-457. [CrossRef] [PubMed]

67. Dimke, H.; Sparks, M.A.; Thomson, B.R.; Frische, S.; Coffman, T.M.; Quaggin, S.E. Tubulovascular cross-talk by vascular endothelial growth factor a maintains peritubular microvasculature in kidney. J. Am. Soc. Nephrol. 2015, 26, 1027-1038. [CrossRef]

68. Kang, H.M.; Ahn, S.H.; Choi, P.; Ko, Y.A.; Han, S.H.; Chinga, F.; Park, A.S.D.; Tao, J.; Sharma, K.; Pullman, J.; et al. Defective fatty acid oxidation in renal tubular epithelial cells has a key role in kidney fibrosis development. Nat. Med. 2015, 21,37-46. [CrossRef]

69. Grammas, P. A damaged microcirculation contributes to neuronal cell death in Alzheimer's disease. In Proceedings of the Neurobiology of Aging. Neurobiol. Aging 2000, 21, 199-205. [CrossRef]

70. Heringa, S.M.; van den Berg, E.; Reijmer, Y.D.; Nijpels, G.; Stehouwer, C.D.A.; Schalkwijk, C.G.; Teerlink, T.; Scheffer, P.G.; van den Hurk, K.; Kappelle, L.J.; et al. Markers of low-grade inflammation and endothelial dysfunction are related to reduced information processing speed and executive functioning in an older population-The Hoorn Study. Psychoneuroendocrinology 2014, 40, 108-118. [CrossRef]

71. Zuliani, G.; Cavalieri, M.; Galvani, M.; Passaro, A.; Munari, M.R.; Bosi, C.; Zurlo, A.; Fellin, R. Markers of endothelial dysfunction in older subjects with late onset Alzheimer's disease or vascular dementia. J. Neurol. Sci. 2008, 272, 164-170. [CrossRef]

72. Borroni, B.; Volpi, R.; Martini, G.; Del Bono, R.; Archetti, S.; Colciaghi, F.; Maalikjy Akkawi, N.; Di Luca, M.; Romanelli, G.; Caimi, L.; et al. Peripheral blood abnormalities in Alzheimer disease: Evidence for early endothelial dysfunction. Alzheimer Dis. Assoc. Disord. 2002, 16, 150-155. [CrossRef] [PubMed]

73. Karin, M.; Greten, F.R. NF-kB: Linking inflammation and immunity to cancer development and progression. Nat. Rev. Immunol. 2005, 5, 749-759. [CrossRef] [PubMed]

74. Ruiz, S.; Pergola, P.E.; Zager, R.A.; Vaziri, N.D. Targeting the transcription factor Nrf2 to ameliorate oxidative stress and inflammation in chronic kidney disease. Kidney Int. 2013, 83, 1029-1041. [CrossRef] [PubMed]

75. Kooman, J.P.; Dekker, M.J.; Usvyat, L.A.; Kotanko, P.; van der Sande, F.M.; Schalkwijk, C.G.; Shiels, P.G.; Stenvinkel, P. Inflammation and premature aging in advanced chronic kidney disease. Am. J. Physiol. Ren. Physiol. 2017, 313, F938-F950. [CrossRef]

76. Amdur, R.L.; Feldman, H.I.; Gupta, J.; Yang, W.; Kanetsky, P.; Shlipak, M.; Rahman, M.; Lash, J.P.; Townsend, R.R.; Ojo, A.; et al. Inflammation and progression of CKD: The CRIC study. Clin. J. Am. Soc. Nephrol. 2016, 11, 1546-1556. [CrossRef]

77. Malhotra, J.D.; Kaufman, R.J. Endoplasmic reticulum stress and oxidative stress: A vicious cycle or a double-edged sword? Antioxid. Redox Signal. 2007, 9, 2277-2293. [CrossRef]

78. Cachofeiro, V.; Goicochea, M.; De Vinuesa, S.G.; Oubĩa, P.; Lahera, V.; Lũo, J. Oxidative stress and inflammation, a link between chronic kidney disease and cardiovascular disease. Kidney Int. Suppl. 2008, 74, S1-S9. [CrossRef]

79. Putri, A.Y.; Thaha, M. Role of oxidative stress on chronic kidney disease progression. Acta Med. Indones. 2014, 46, 244-252.

80. Vinothkumar, G.; Kedharnath, C.; Krishnakumar, S.; Sreedhar, S.; Preethikrishnan, K.; Dinesh, S.; Sundaram, A.; Balakrishnan, D.; Shivashekar, G.; Kumar, S.; et al. Abnormal amyloid $\beta 42$ expression and increased oxidative stress in plasma of CKD patients with cognitive dysfunction: A small scale case control study comparison with Alzheimer's disease. BBA Clin. 2017, 8, 20-27. [CrossRef]

81. Roses, A.D. Apolipoprotein E genotyping in the differential diagnosis, not prediction, of Alzheimer's disease. Ann. Neurol. 1995, 38, 6-14. [CrossRef]

82. Roses, A.D. Apolipoprotein E and Alzheimer's disease: A rapidly expanding field with medical and epidemiological consequences. In Annals of the New York Academy of Sciences; Blackwell Publishing Inc.: Malden, MA, USA, 1996; Volume 802, pp. 50-57.

83. Butterfield, D.A.; Reed, T.; Newman, S.F.; Sultana, R. Roles of amyloid $\beta$-peptide-associated oxidative stress and brain protein modifications in the pathogenesis of Alzheimer's disease and mild cognitive impairment. Free Radic. Biol. Med. 2007, 43, 658-677. [CrossRef] [PubMed] 
84. Rapa, S.F.; Di Iorio, B.R.; Campiglia, P.; Heidland, A.; Marzocco, S. Inflammation and oxidative stress in chronic kidney disease-Potential therapeutic role of minerals, vitamins and plant-derived metabolites. Int. J. Mol. Sci. 2020, 21, 263. [CrossRef] [PubMed]

85. Abiodun, O.A.; Ola, M.S. Role of brain renin angiotensin system in neurodegeneration: An update. Saudi J. Biol. Sci. 2020, 27, 905-912. [CrossRef] [PubMed]

86. Patel, S.; Rauf, A.; Khan, H.; Abu-Izneid, T. Renin-angiotensin-aldosterone (RAAS): The ubiquitous system for homeostasis and pathologies. Biomed. Pharmacother. 2017, 94, 317-325. [CrossRef] [PubMed]

87. Nanjundaiah, S.; Chidambaram, H.; Chandrashekar, M.; Chinnathambi, S. Role of Microglia in Regulating Cholesterol and Tau Pathology in Alzheimer's Disease. Cell. Mol. Neurobiol. 2020, 1-18. [CrossRef] [PubMed]

88. Serban, D.; Anton, E.; Chirita, R.; Bild, V.; Ciobica, A.; Alexinschi, O.; Arcan, O.; Popescu, R.; Paduraru, L.; Timofte, D. Current aspects of the interactions between dementia, the brain renin-angiotensin system and oxidative stress. Arch. Biol. Sci. 2015, 67, 903-907. [CrossRef]

89. Wright, J.W.; Harding, J.W. Brain renin-angiotensin-A new look at an old system. Prog. Neurobiol. 2011, 95, 49-67. [CrossRef]

90. Singh, K.D.; Karnik, S.S. Angiotensin Receptors: Structure, Function, Signaling and Clinical Applications. J. cell Signal. 2016, 1, 111.

91. McKinley, M.J.; Albiston, A.L.; Allen, A.M.; Mathai, M.L.; May, C.N.; McAllen, R.M.; Oldfield, B.J.; Mendelsohn, F.A.O.; Chai, S.Y. The brain renin-angiotensin system: Location and physiological roles. Int. J. Biochem. Cell Biol. 2003, 35, 901-918. [CrossRef]

92. Saavedra, J.M. Beneficial effects of Angiotensin II receptor blockers in brain disorders. Pharmacol. Res. 2017, 125, 91-103. [CrossRef]

93. Torika, N.; Asraf, K.; Danon, A.; Apte, R.N.; Fleisher-Berkovich, S. Telmisartan Modulates Glial Activation: In Vitro and In Vivo Studies. PLoS ONE 2016, 11, e0155823. [CrossRef]

94. Blennow, K.; Zetterberg, H. Biomarkers for Alzheimer's disease: Current status and prospects for the future. J. Intern. Med. 2018, 284, 643-663. [CrossRef] [PubMed]

95. Quitterer, U.; AbdAlla, S. Improvements of symptoms of Alzheimer's disease by inhibition of the angiotensin system. Pharmacol. Res. 2020, 154, 104230. [CrossRef] [PubMed]

96. Kanemaru, K.; Kanemaru, A.; Murayama, S. Association between Renal Functions and CSF Biomarkers in Alzheimer's Disease. Alzheimer's Dement. 2016, 12, P665. [CrossRef]

97. Hansson, O.; Zetterberg, H.; Vanmechelen, E.; Vanderstichele, H.; Andreasson, U.; Londos, E.; Wallin, A.; Minthon, L.; Blennow, K. Evaluation of plasma A $\beta 40$ and A $\beta 42$ as predictors of conversion to Alzheimer's disease in patients with mild cognitive impairment. Neurobiol. Aging 2010, 31, 357-367. [CrossRef] [PubMed]

98. Zhou, Y.; Shi, J.; Chu, D.; Hu, W.; Guan, Z.; Gong, C.X.; Iqbal, K.; Liu, F. Relevance of phosphorylation and truncation of tau to the etiopathogenesis of Alzheimer's disease. Front. Aging Neurosci. 2018, 10, 27. [CrossRef]

99. Li, L.; Jiang, Y.; Hu, W.; Tung, Y.C.; Dai, C.; Chu, D.; Gong, C.X.; Iqbal, K.; Liu, F. Pathological Alterations of Tau in Alzheimer's Disease and 3xTg-AD Mouse Brains. Mol. Neurobiol. 2019, 56, 6168-6183. [CrossRef]

100. Harrington, C.R.; Wischik, C.M.; McArthur, F.K.; Taylor, G.A.; Edwardson, J.A.; Candy, J.M. Alzheimer's-disease-like changes in tau protein processing: Association with aluminium accumulation in brains of renal dialysis patients. Lancet 1994, 343, 993-997. [CrossRef]

101. Smith, A.D.; Refsum, H.; Bottiglieri, T.; Fenech, M.; Hooshmand, B.; McCaddon, A.; Miller, J.W.; Rosenberg, I.H.; Obeid, R. Homocysteine and Dementia: An International Consensus Statement. J. Alzheimer's Dis. 2018, 62, 561-570. [CrossRef]

102. Stanciu, G.D.; Solcan, G. Acute idiopathic polyradiculoneuritis concurrent with acquired myasthenia gravis in a West Highland white terrier dog. BMC Vet. Res. 2016, 12, 111. [CrossRef]

103. Lai, W.K.C.; Kan, M.Y. Homocysteine-induced endothelial dysfunction. Ann. Nutr. Metab. 2015, 67, 1-12. [CrossRef] [PubMed]

104. Karmin, O.; Siow, Y.L. Metabolic Imbalance of Homocysteine and Hydrogen Sulfide in Kidney Disease. Curr. Med. Chem. 2017, 25, 367-377.

105. Ohishi, T.; Fujita, T.; Suzuki, D.; Nishida, T.; Asukai, M.; Matsuyama, Y. Serum homocysteine levels are affected by renal function during a 3-year period of minodronate therapy in female osteoporotic patients. J. Bone Miner. Metab. 2019, 37, 319-326. [CrossRef] [PubMed]

106. Hernandez, F.; Lucas, J.J.; Avila, J. GSK3 and tau: Two convergence points in Alzheimer's disease. J. Alzheimer's Dis. 2013, 33, S141-S144. [CrossRef] 
107. Johnson, K.A.; Schultz, A.; Betensky, R.A.; Becker, J.A.; Sepulcre, J.; Rentz, D.; Mormino, E.; Chhatwal, J.; Amariglio, R.; Papp, K.; et al. Tau positron emission tomographic imaging in aging and early Alzheimer disease. Ann. Neurol. 2016, 79, 110-119. [CrossRef]

108. Reddy, P.H. Amyloid beta-induced glycogen synthase kinase $3 \beta$ phosphorylated VDAC1 in Alzheimer's disease: Implications for synaptic dysfunction and neuronal damage. Biochim. Biophys. Acta Mol. Basis Dis. 2013, 1832, 1913-1921. [CrossRef]

109. Vinothkumar, G.; Krishnakumar, S.; Venkataraman, P. Correlation between abnormal GSK3 $\beta$, $\beta$ Amyloid, total Tau, p-Tau 181 levels and neuropsychological assessment total scores in CKD patients with cognitive dysfunction: Impact of rHuEPO therapy. J. Clin. Neurosci. 2019, 69, 38-42. [CrossRef]

110. Kuhle, J.; Barro, C.; Andreasson, U.; Derfuss, T.; Lindberg, R.; Sandelius, A.; Liman, V.; Norgren, N.; Blennow, K.; Zetterberg, H. Comparison of three analytical platforms for quantification of the neurofilament light chain in blood samples: ELISA, electrochemiluminescence immunoassay and Simoa. Clin. Chem. Lab. Med. 2016, 54, 1655-1661. [CrossRef]

111. Weston, P.S.J.; Poole, T.; Ryan, N.S.; Nair, A.; Liang, Y.; Macpherson, K.; Druyeh, R.; Malone, I.B.; Ahsan, R.L.; Pemberton, H.; et al. Serum neurofilament light in familial Alzheimer disease: A marker of early neurodegeneration. Neurology 2017, 89, 2167-2175. [CrossRef]

112. Stevenson, A.; Lopez, D.; Khoo, P.; Kalaria, R.N.; Mukaetova-Ladinska, E.B. Exploring Erythrocytes as Blood Biomarkers for Alzheimer's Disease. J. Alzheimer's Dis. 2017, 60, 845-857. [CrossRef]

113. Heneka, M.T.; Carson, M.J.; El Khoury, J.; Landreth, G.E.; Brosseron, F.; Feinstein, D.L.; Jacobs, A.H.; Wyss-Coray, T.; Vitorica, J.; Ransohoff, R.M.; et al. Neuroinflammation in Alzheimer's disease. Lancet Neurol. 2015, 14, 388-405. [CrossRef]

114. Muramatsu, T.; Matsushita, S.; Arai, H.; Sasaki, H.; Higuchi, S. $\alpha 1$-Antichymotrypsin gene polymorphism and risk for Alzheimer's disease. J. Neural Transm. 1996, 103, 1205-1210. [CrossRef]

115. Pirttila, T.; Mehta, P.D.; Frey, H.; Wisniewski, H.M. $\alpha 1$-Antichymotrypsin and IL-1 $\beta$ are not increased in CSF or serum in Alzheimer's disease. Neurobiol. Aging 1994, 15, 313-317. [CrossRef]

116. Duranton, F.; Cohen, G.; De Smet, R.; Rodriguez, M.; Jankowski, J.; Vanholder, R.; Argiles, A. Normal and pathologic concentrations of uremic toxins. J. Am. Soc. Nephrol. 2012, 23, 1258-1270. [CrossRef] [PubMed]

117. Movilli, E.; Camerini, C.; Gaggia, P.; Poiatti, P.; Pola, A.; Viola, B.F.; Zubani, R.; Jeannin, G.; Cancarini, G. Effect of post-dilutional on-line haemodiafiltration on serum calcium, phosphate and parathyroid hormone concentrations in uraemic patients. Nephrol. Dial. Transpl. 2011, 26, 4032-4037. [CrossRef]

118. Neirynck, N.; Vanholder, R.; Schepers, E.; Eloot, S.; Pletinck, A.; Glorieux, G. An update on uremic toxins. Int. Urol. Nephrol. 2013, 45, 139-150. [CrossRef]

119. Souberbielle, J.C.P.; Roth, H.; Fouque, D.P. Parathyroid hormone measurement in CKD. Kidney Int. 2010, 77, 93-100. [CrossRef]

120. Lishmanov, A.; Dorairajan, S.; Pak, Y.; Chaudhary, K.; Chockalingam, A. Elevated serum parathyroid hormone is a cardiovascular risk factor in moderate chronic kidney disease. Int. Urol. Nephrol. 2012, 44, 541-547. [CrossRef]

121. Anderson, J.L.; Vanwoerkom, R.C.; Horne, B.D.; Bair, T.L.; May, H.T.; Lappé, D.L.; Muhlestein, J.B. Parathyroid hormone, vitamin $\mathrm{D}$, renal dysfunction, and cardiovascular disease: Dependent or independent risk factors? Am. Heart J. 2011, 162, 331-339. [CrossRef]

122. Bhuriya, R.; Li, S.; Chen, S.C.; McCullough, P.A.; Bakris, G.L. Plasma Parathyroid Hormone Level and Prevalent Cardiovascular Disease in CKD Stages 3 and 4: An Analysis From the Kidney Early Evaluation Program (KEEP). Am. J. Kidney Dis. 2009, 53, S3-S10. [CrossRef]

123. Lourida, I.; Thompson-Coon, J.; Dickens, C.M.; Soni, M.; Kuźma, E.; Kos, K.; Llewellyn, D.J. Parathyroid hormone, cognitive function and dementia: A systematic review. PLOS ONE 2015, 10, e0127574. [CrossRef] [PubMed]

124. Çermik, T.F.; Kaya, M.; Uğur-Altun, B.; Bedel, D.; Berkarda, Ş.; Yiğitbaşı, Ö.N. Regional cerebral blood flow abnormalities in patients with primary hyperparathyroidism. Neuroradiology 2007, 49, 379-385. [CrossRef] [PubMed]

125. Bonelli, R.M.; Cummings, J.L. Frontal-Subcortical Dementias. Neurologist 2008, 14, 100-107. [CrossRef] [PubMed]

126. Levin, A.; Bakris, G.L.; Molitch, M.; Smulders, M.; Tian, J.; Williams, L.A.; Andress, D.L. Prevalence of abnormal serum vitamin D, PTH, calcium, and phosphorus in patients with chronic kidney disease: Results of the study to evaluate early kidney disease. Kidney Int. 2007, 71, 31-38. [CrossRef] 
127. Block, G.A.; Klassen, P.S.; Lazarus, J.M.; Ofsthun, N.; Lowrie, E.G.; Chertow, G.M. Mineral metabolism, mortality, and morbidity in maintenance hemodialysis. J. Am. Soc. Nephrol. 2004, 15, 2208-2218. [CrossRef]

128. Shanahan, C.M.; Crouthamel, M.H.; Kapustin, A.; Giachelli, C.M. Arterial calcification in chronic kidney disease: Key roles for calcium and phosphate. Circ. Res. 2011, 109, 697-711. [CrossRef]

129. Bild, V.; Ababei, D.C.; Neamtu, M.; Vasincu, A.; Bild, W.; Stanciu, G.D.; Tamba, B.I.; Solcan, G.; Beschea Chiriac, S. Isobolar analysis of the binary fixed-ratio combination of acetylsalicilic acid-acetaminophen. Farmacia 2017, 65, 563-566.

130. Filiopoulos, V.; Hadjiyannakos, D.; Vlassopoulos, D. New insights into uric acid effects on the progression and prognosis of chronic kidney disease. Ren. Fail. 2012, 34, 510-520. [CrossRef]

131. Nashar, K.; Fried, L.F. Hyperuricemia and the Progression of Chronic Kidney Disease: Is Uric Acid a Marker or an Independent Risk Factor? Adv. Chronic Kidney Dis. 2012, 19, 386-391. [CrossRef]

132. Dousdampanis, P.; Trigka, K.; Musso, C.G.; Fourtounas, C. Hyperuricemia and chronic kidney disease: An enigma yet to be solved. Ren. Fail. 2014, 36, 1351-1359. [CrossRef]

133. Liu, W.C.; Tomino, Y.; Lu, K.C. Impacts of indoxyl sulfate and p-Cresol sulfate on chronic kidney disease and mitigating effects of AST-120. Toxins 2018, 10, 367. [CrossRef] [PubMed]

134. Fujii, H.; Goto, S.; Fukagawa, M. Role of uremic toxins for kidney, cardiovascular, and bone dysfunction. Toxins 2018, 10, 202. [CrossRef] [PubMed]

135. Tan, X.; Cao, X.; Zou, J.; Shen, B.; Zhang, X.; Liu, Z.; Lv, W.; Teng, J.; Ding, X. Indoxyl sulfate, a valuable biomarker in chronic kidney disease and dialysis. Hemodial. Int. 2017, 21, 161-167. [CrossRef] [PubMed]

136. Jaffe, J.A.; Liftman, C.; Glickman, J.D. Frequency of elevated serum aluminum levels in adult dialysis patients. Am. J. Kidney Dis. 2005, 46, 316-319. [CrossRef] [PubMed]

137. Tsai, M.H.; Fang, Y.W.; Liou, H.H.; Leu, J.G.; Lin, B.S. Association of Serum Aluminum Levels with Mortality in Patients on Chronic Hemodialysis. Sci. Rep. 2018, 8, 1-9. [CrossRef] [PubMed]

138. Peralta, C.A.; Katz, R.; Sarnak, M.J.; Ix, J.; Fried, L.F.; De Boer, I.; Palmas, W.; Siscovick, D.; Levey, A.S.; Shlipak, M.G. Cystatin C identifies chronic kidney disease patients at higher risk for complications. J. Am. Soc. Nephrol. 2011, 22, 147-155. [CrossRef] [PubMed]

139. DSa, J.; Shetty, S.; Bhandary, R.R.; Rao, A. V Association Between Serum Cystatin C and Creatinine in Chronic Kidney Disease Subjects Attending a Tertiary Health Care Centre. J. Clin. Diagn. Res. 2017, 11, BC09. [CrossRef]

140. Sastre, M.; Calero, M.; Pawlik, M.; Mathews, P.M.; Kumar, A.; Danilov, V.; Schmidt, S.D.; Nixon, R.A.; Frangione, B.; Levy, E. Binding of cystatin $C$ to Alzheimer's amyloid $\beta$ inhibits in vitro amyloid fibril formation. Neurobiol. Aging 2004, 25, 1033-1043. [CrossRef]

141. Mathews, P.M.; Levy, E. Cystatin C in aging and in Alzheimer's disease. Ageing Res. Rev. 2016, 32, 38-50. [CrossRef]

142. Wang, C.; Sun, B.; Zhou, Y.; Grubb, A.; Gan, L. Cathepsin B degrades amyloid- $\beta$ in mice expressing wild-type human amyloid precursor protein. J. Biol. Chem. 2012, 287, 39834-39841. [CrossRef]

143. Wang, B.; Xie, Y.; Yang, Z.; Peng, D.; Wang, J.; Zhou, S.; Li, S.; Ma, X. Lack of an Association between Alzheimer's Disease and the Cystatin C (CST3) Gene G73A Polymorphism in Mainland Chinese. Dement. Geriatr. Cogn. Disord. 2008, 25, 461-464. [CrossRef] [PubMed]

144. Beyer, K.; Lao, J.I.; Gómez, M.; Riutort, N.; Latorre, P.; Mate, J.L.; Ariza, A. Alzheimer's disease and the cystatin C gene polymorphism: An association study. Neurosci. Lett. 2001, 315, 17-20. [CrossRef]

145. Stanciu, G.-D.; Packer, R.M.A.; Pakozdy, A.; Solcan, G.; Volk, H.A. Clinical reasoning in feline epilepsy: Which combination of clinical information is useful? Vet. J. 2017, 225, 9-12. [CrossRef] [PubMed]

146. Oh, S.W.; Kim, S.; Na, K.Y.; Kim, K.W.; Chae, D.W.; Chin, H.J. Glomerular filtration rate and proteinuria: Association with mortality and renal progression in a prospective cohort of a community-based elderly population. PLoS ONE 2014, 9, e94120. [CrossRef] [PubMed]

147. Selkoe, D.J. Alzheimer's Disease: Genes, Proteins, and Therapy. Physiol. Rev. 2001, 81, 741-766. [CrossRef]

148. Mawuenyega, K.G.; Sigurdson, W.; Ovod, V.; Munsell, L.; Kasten, T.; Morris, J.C.; Yarasheski, K.E.; Bateman, R.J. Decreased clearance of CNS $\beta$-amyloid in Alzheimer's disease. Science 2010, 330, 1774. [CrossRef]

149. Yuede, C.M.; Lee, H.; Restivo, J.L.; Davis, T.A.; Hettinger, J.C.; Wallace, C.E.; Young, K.L.; Hayne, M.R.; Bu, G.; $\mathrm{Li}, \mathrm{C}$;; et al. Rapid in vivo measurement of $\beta$-amyloid reveals biphasic clearance kinetics in an Alzheimer's mouse model. J. Exp. Med. 2016, 213, 677-685. [CrossRef] 
150. Qosa, H.; Abuasal, B.S.; Romero, I.A.; Weksler, B.; Couraud, P.O.; Keller, J.N.; Kaddoumi, A. Differences in amyloid- $\beta$ clearance across mouse and human blood-brain barrier models: Kinetic analysis and mechanistic modeling. Neuropharmacology 2014, 79, 668-678. [CrossRef]

151. Wang, L.; Zhang, Y.; Zhao, Y.; Marshall, C.; Wu, T.; Xiao, M. Deep cervical lymph node ligation aggravates AD-like pathology of APP/PS1 mice. Brain Pathol. 2019, 29, 176-192. [CrossRef]

152. Jin, W.-S.; Shen, L.-L.; Bu, X.-L.; Zhang, W.-W.; Chen, S.-H.; Huang, Z.-L.; Xiong, J.-X.; Gao, C.-Y.; Dong, Z.; He, Y.-N.; et al. Peritoneal dialysis reduces amyloid-beta plasma levels in humans and attenuates Alzheimer-associated phenotypes in an APP/PS1 mouse model. Acta Neuropathol. 2017, 134, 207-220. [CrossRef]

153. Liu, Y.H.; Xiang, Y.; Wang, Y.R.; Jiao, S.S.; Wang, Q.H.; Bu, X.-L.; Zhu, C.; Yao, X.Q.; Giunta, B.; Tan, J.; et al. Association Between Serum Amyloid-Beta and Renal Functions: Implications for Roles of Kidney in Amyloid-Beta Clearance. Mol. Neurobiol. 2015, 52, 115-119. [PubMed]

154. Stanciu, G.D.; Musteaţă, M.; Armaşu, M.; Solcan, G. Evaluation of central vestibular syndrome in dogs using brainstem auditory evoked responses recorded with surface electrodes. Arq. Bras. Med. Vet. e Zootec. 2016, 68. [CrossRef]

155. Xiang, Y.; Bu, X.-L.; Liu, Y.-H.; Zhu, C.; Shen, L.-L.; Jiao, S.-S.; Zhu, X.-Y.; Giunta, B.; Tan, J.; Song, W.-H.; et al. Physiological amyloid-beta clearance in the periphery and its therapeutic potential for Alzheimer's disease. Acta Neuropathol. 2015, 130, 487-499. [CrossRef] [PubMed]

156. Kitaguchi, N.; Hasegawa, M.; Ito, S.; Kawaguchi, K.; Hiki, Y.; Nakai, S.; Suzuki, N.; Shimano, Y.; Ishida, O.; Kushimoto, H.; et al. A prospective study on blood $\mathrm{A} \beta$ levels and the cognitive function of patients with hemodialysis: A potential therapeutic strategy for Alzheimer's disease. J. Neural Transm. 2015, 122, 1593-1607. [CrossRef]

157. Kitaguchi, N.; Kawaguchi, K.; Nakai, S.; Murakami, K.; Ito, S.; Hoshino, H.; Hori, H.; Ohashi, A.; Shimano, Y.; Suzuki, N.; et al. Reduction of Alzheimer's disease amyloid- $\beta$ in plasma by hemodialysis and its relation to cognitive functions. Blood Purif. 2011, 32, 57-62. [CrossRef]

158. Kato, M.; Kawaguchi, K.; Nakai, S.; Murakami, K.; Hori, H.; Ohashi, A.; Hiki, Y.; Ito, S.; Shimano, Y.; Suzuki, N.; et al. Potential therapeutic system for Alzheimer's disease: Removal of blood A $\beta$ s by hemodialzyers and its effect on the cognitive functions of renal-failure patients. J. Neural Transm. 2012, 119, 1533-1544. [CrossRef] [PubMed]

159. Tholen, S.; Schmaderer, C.; Chmielewski, S.; Förstl, H.; Heemann, U.; Baumann, M.; Steubl, D.; Grimmer, T. Reduction of Amyloid- $\beta$ Plasma Levels by Hemodialysis: An Anti-Amyloid Treatment Strategy? J. Alzheimer's Dis. 2016, 50, 791-796. [CrossRef] [PubMed] 